\title{
ANALISIS INVESTASI SAHAM SUBSEKTOR PROPERTI DAN REAL ESTATE DI INDONESIA
}

(Studi pada Tujuh Belas Emiten Properti dan Real Estate yang Terdaftar di Bursa Efek Indonesia)

\author{
Hanif Hasana Jamil ${ }^{1}$ \\ Efri Diah Utami ${ }^{2}$ \\ Alumni STIS Jakarta ${ }^{1}$, Dosen STIS Jakarta ${ }^{2}$ \\ Jl. Otto Iskandardinata No. 64 C Jakarta ${ }^{1,2}$ \\ Email: efridiah@stis.ac.id ${ }^{l}$
}

\begin{abstract}
ABSTRAK
Dalam dua tahun terakhir, pergerakan indeks harga saham sektor properti menunjukkan pergerakan paling fluktuatif dibandingkan dengan sektor lain di Bursa Efek Indonesia. Hal ini juga terlihat dari pergerakan harga saham dari emiten subsektor properti dan real estate. Empat belas dari tujuh belas emiten yang listing sejak awal tahun 2009 mengalami penurunan harga saham cukup tajam pada kuartal III tahun 2013, setelah sebelumnya mengalami kenaikan. Kondisi ini menunjukkan tingginya risiko dalam investasi saham subsektor properti dan real estate. Tujuan penelitian ini yaitu menganalisis tingkat kewajaran harga saham dengan pendekatan Price Earning Ratio (PER) serta menganalisis pengaruh kondisi makroekonomi dan kinerja keuangan emiten terhadap harga saham properti dan real estate tahun 2009-2013. Hasil penelitian menunjukkan bahwa berdasarkan pendekatan PER, secara umum harga saham emiten yang menjadi objek penelitian masih relatif murah sehingga masih relatif aman untuk dijadikan instrumen investasi. Hasil analisis regresi panel dengan model fixed effect seemingly unrelated regression (SUR) menunjukkan bahwa terdapat lima variabel yang signifikan berpengaruh terhadap harga saham emiten properti dan real estate. Pertumbuhan ekonomi, Return on Asset (ROA) dan Book Value per Share (BV) berpengaruh positif, sedangkan nilai tukar riil rupiah terhadap dolar dan BI rate memberikan pengaruh negatif terhadap harga saham emiten properti dan real estate.
\end{abstract}

\section{PENDAHULUAN}

Secara faktual, pasar modal telah menjadi pusat saraf finansial pada dunia ekonomi modern seperti sekarang ini. Perekonomian modern tidak akan mungkin dapat bertahan tanpa adanya pasar modal yang tangguh, berdaya saing global, dan terorganisir dengan baik (Bapepam, 2004). Banyak perusahaan yang menjadikan institusi ini sebagai media untuk menyerap investasi dan memperkuat posisi keuangan mereka. Investasi di pasar modal, khususnya saham,juga dinilai lebih menjanjikan karena mempunyai pengembalian relatif tinggi dibandingkan instrumen investasi lain seperti emas, perak, dan properti.
Di antara sembilan sektor di Bursa Efek Indonesia (BEI), saham sektor properti merupakan salah satu pilihan investasi yang banyak diminati. Hal ini terlihat dari besarnya volume perdagangan saham sektor ini. Dalam tiga tahun terakhir, volume perdagangan sektor ini selalu mengalami kenaikan. Bahkan, sektor properti memilikipersentase volume perdagangan saham paling tinggi pada tahun 2013, yaitu sebesar 26 persen (gambar 1).Daya tarik investasi saham sektor properti juga didorong oleh harga properti dan real estateyang cenderung mengalami kenaikan. Kenaikan harga ini disebabkan industri properti memiliki suplai lahan terbatas sementara permintaannya cenderung bertambah. 


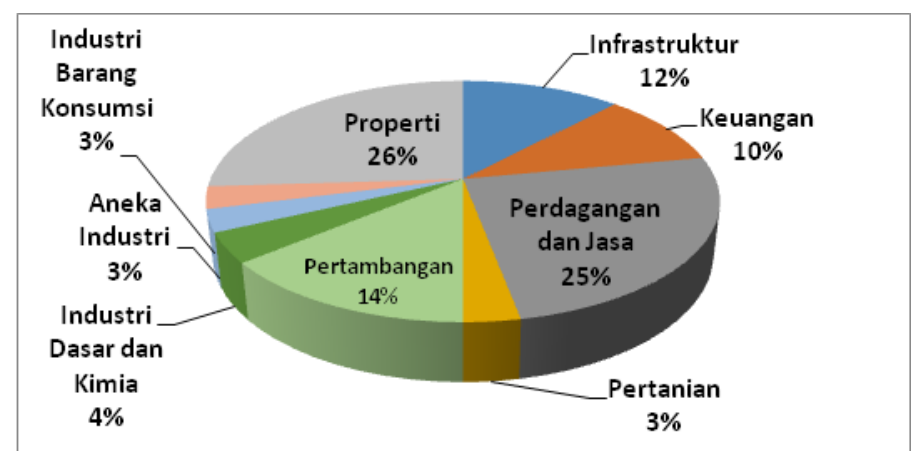

Sumber: Bursa Efek Indonesia, diolah

Gambar 1. Persentase volume perdagangan saham menurut sektor tahun 2013

Namun demikian, daya tarik investasi saham di sektor properti tersebut tidak menjadikan harga saham sektor properti terhindar dari hal-hal yang layak dijadikan pertimbangan dalam investasi. Seperti yang dikatakan oleh Hijriah (2007), pertumbuhan investasi di sektor properti pada umumnya sangat sensitif terhadap indikator makroekonomi. Misalnya sajapada tahun 2008, terjadinya krisis finansial global yang dikenal sebagai krisis subprime mortgage di Amerika Serikat mengakibatkan indeks harga saham sektor properti merosot 120,67 persen pada akhir 2008.Penurunan tersebut jauh lebih tinggi dibandingkan dengan penurunan IHSG sebesar 77,01 persen. Dibandingkan dengan delapan sektor lain, pergerakan indeks harga saham properti dalam dua tahun terakhir juga tercatat memiliki fluktuasi yang paling tinggi, hampir mencapai 150 persen (gambar 2).

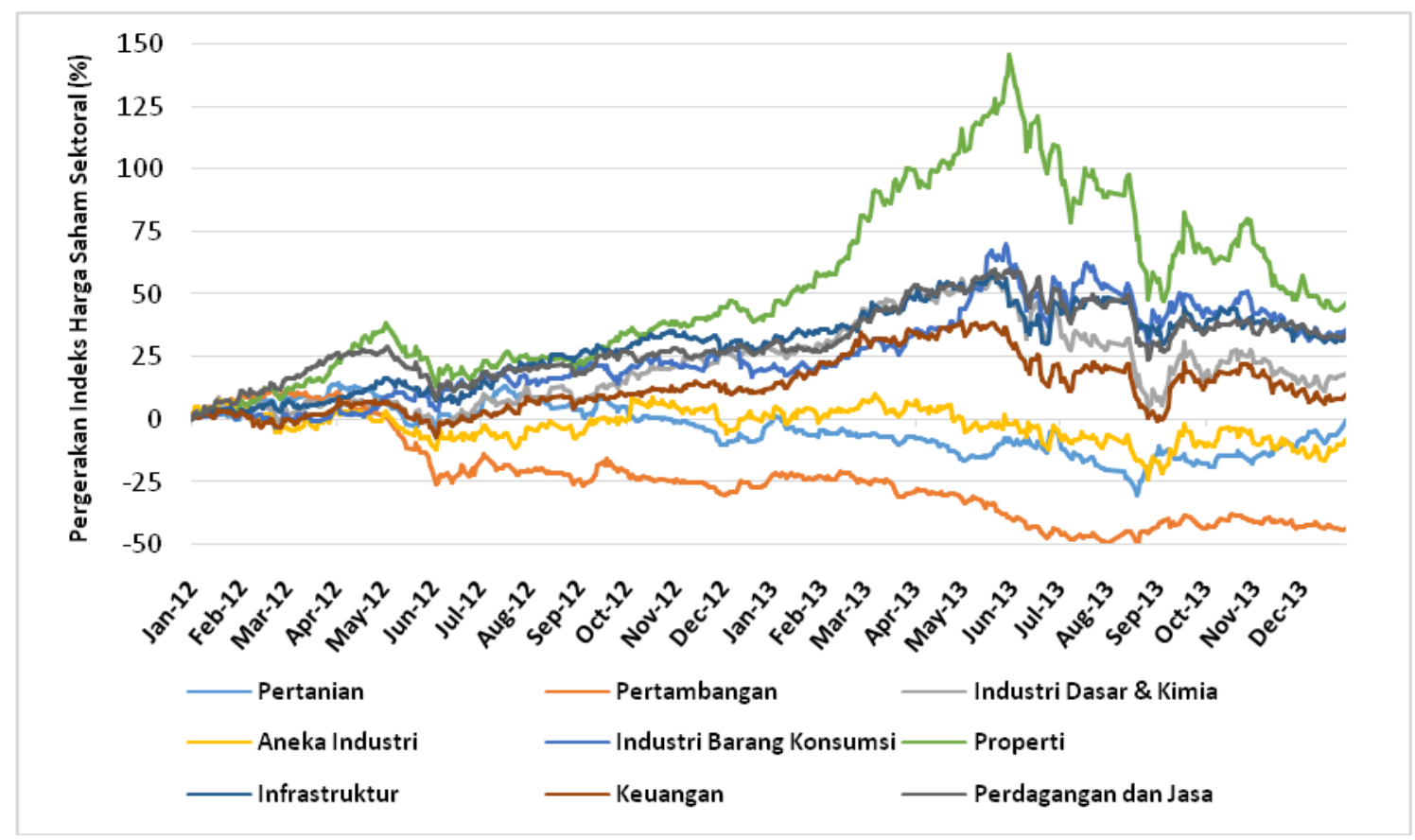

Sumber: Bursa Efek Indonesia, diolah

Gambar 2. Pergerakan indeks harga saham sembilan sektor di BEI pada Januari 2012Desember 2013 
Setelah mengalami peningkatan yang signifikan pada awal tahun 2013, pergerakan indeks harga saham properti berbalik arah pada kuartal III tahun 2013, merosot tajam sebesar 20,53 persen dibandingkan dengan kuartal sebelumnya. Merosotnya indeks harga saham sektor properti ini merupakan yang pertama semenjak krisis finansial global pada tahun 2008. Bahkan, merosotnya indeks harga saham sektor properti ini diikuti dengan penurunan nilai kapitalisasi pasar sektor ini sebesar 17,04 persen.

Fluktuasi harga saham sektor properti tersebut terlihat juga pada pergerakan harga saham emitennya. Dari tujuh belas emiten properti yang listing sejak awal tahun 2009, terdapat empat belas emiten yang mengalami penurunan harga saham pada kuartal III tahun 2013 dengan rata-rata penurunan harga saham mencapai 25 persen, setelah sebelumnya mengalamipeningkatan yang cukup tajam. Selain itu, data Bloomberg menunjukkan empat saham emiten properti masuk dalam sepuluh besar saham paling volatil selama tahun 2013, yaitu saham Ciputra Development Tbk, Pakuwon Jati Tbk, Jaya Property Tbk, dan Summarecon Agung Tbk. Volatilitas saham-saham emiten properti tersebut berada pada level 49-67 persen.

Menurut Kartika (2010), seorang investor harus berhati-hati terhadappergerakan harga saham yang terlalu cepat naikatau terlalu cepat turun dengan tajam. Tingginya fluktuasi harga saham menunjukkan bahwa saham tersebut memiliki risiko yang tinggi karena tingkat pengembalian yang diperoleh dari investasi tersebut menjadi semakin tidak pasti. Dengan demikian, tingginya fluktuasi harga saham pada sektor properti pada beberapa periode terakhir menunjukkan bahwa investor harus benar-benar mampu melakukan penilaian atas saham-saham sektor properti agar terhindar dari kerugian.
Dalam penelitian ini, penilaian saham dilakukan dengan pendekatan Price Earning Ratio (PER). Penilaian saham juga dapat dilakukan dengan melakukan suatu mekanisme untuk mengubah serangkaian variabel ekonomi atau variabel perusahaan menjadi perkiraan harga saham (Husnan, 1993). Variabel makroekonomi yang digunakan dalam penelitian ini yaitu pertumbuhan ekonomi, nilai tukar riil rupiah terhadap dolar, dan BI Rate. Sedangkan variabel yang menunjukkan kinerja emiten yang digunakan yaitu Return on Asset (ROA), Debt to Asset Ratio (DAR), dan Book Value per Share (BV).

Penelitian ini akan difokuskan pada subsektor properti dan real estate dengan pertimbangan bahwa subsektor ini memiliki nilai kapitalisasi pasar yang jauh lebih besar dibandingkan dengan sektor konstruksi. Berdasarkan data BEItahun 2013, nilai kapitalisasi pasar subsektor properti dan real estate mencapai 84 persen dari total nilai kapitalisasi sektornya. Selain itu, banyak perusahaan pada subsektor konstruksi yang delisting selama periode penelitian yang digunakan.

Tujuan penelitian ini: 1) Menganalisis tingkat kewajaran dan pergerakan harga saham emiten subsektor properti dan real estatetahun 2009-2013, 2) Menganalisis gambaran umum kondisi makroekonomi dan kinerja emiten subsektor properti dan real estatetahun 2009-2013, dan 3) Menganalisis pengaruh kondisi makroekonomi dan kinerja emiten terhadap harga saham emiten subsektor properti dan real estatetahun 2009-2013.

\section{METODOLOGI}

Price Earning Ratio (PER)
menunjukkan rasio harga saham
terhadap earnings. Besarnya PER
menunjukkan seberapa besar investor
menilai harga dari saham terhadap
kelipatan dari laba per lembar saham
yang dimiliki perusahaan. Perhitungan


PER dari suatu perusahaan adalah sebagai berikut. (Hanafi dan Abdul, 2000)

$$
\text { PER }=\frac{\text { Harga Saham }}{\text { Earning Per Share }}
$$

Penilaian Price Earning Ratio (PER)dapat dilakukan dengan menghubungkan PER perusahaan dengan PER rata-rata pasar atau rata-rata kelompok industri tertentu, sehingga dapat dilakukan penilaian kinerja relatif suatu perusahaan (Husnan, 1993).

Menurut Arifin (2007), ada beberapa faktor yang harus disadari oleh setiap investor yang memicu berfluktuasinya harga saham, yaitu faktor yang bersifat mikro dan faktor yang bersifat makro. Faktor mikro adalah faktor-faktor yang dampaknya hanya terhadap beberapa jenis saham saja, sedangkan faktor makro yaitu faktor penyebab yang berdampak pada semua saham atau keseluruhan bursa.

Dalam penelitian inidigunakan data sekunder dariPublikasi BEI IDX Statistics Quarterly, laporan keuangan triwulanan setiapemiten yang menjadi objek penelitian, Badan Pusat Statistik, Bank Indonesia, dan OECD (Organisation for Economic Cooperation and Development). Data tersebut yaitu total aset, total kewajiban, laba bersih, nilai buku per lembar saham I Book Value per Share (BV), laba bersih per lembar saham / Earning per Share (EPS), harga saham penutupan, PDB ADHK 2000, BI Rate, nilai tukar nominal rupiah terhadap dolar, IHK Indonesia, dan IHK Amerika.

Analisis yang digunakan dalam penelitian ini meliputi analisis deskriptif dan analisis inferensia. Analisis deskriptif digunakan dengan penyajian data melalui tabel dan grafik. Sedangkan analisis inferensia yang digunakan yaitu analisis regresi data panel dengan tujuh belas emiten subsektor properti dan real estatedan periode tahun 2009 kuartal I tahun 2013 kuartal III. Analisis regresi data panel digunakan untuk menganalisis pengaruh pertumbuhan ekonomi, nilai tukar riil rupiah terhadap dolar, BI Rate, Return on Asset (ROA), Debt to Asset Ratio (DAR), dan Book Value per Share (BV) terhadap harga saham emiten properti dan real estate. Hipotesis penelitian ini yaitu pertumbuhan ekonomi, ROA, dan BV berpengaruh positif terhadap harga saham, sementara BI Rate, nilai tukar rupiah terhadap dolar dan DAR berpengaruh negatif terhadap harga saham.

\section{HASIL DAN PEMBAHASAN}

Penilaian tingkat kewajaran harga saham emiten properti dan real estate dengan membandingkan PER setiap emiten dengan PER subsektor menunjukkan bahwa secara historis dari tahun 2009 hingga 2012 terdapat sepuluh emiten dengan PER yang selalu berada di bawah PER subsektor (tabel 1). Dengan demikian, kesepuluh saham tersebut dapat dikatakan relatif murah atau underpriced.Sebaliknya, hanya terdapat tujuh emiten di mana PER sahamnya pernah melebihi PER subsektor. Ketujuh emiten tersebut yaitu Ciputra Development Tbk (CTRA), Ciputra Properti Tbk (CTRP), Danayasa Arthatama Tbk (SCBD), Duta Anggada Realty Tbk (DART), Lippo Karawaci Tbk (LPKR), Modernland Realty Tbk (MDLN), dan Summarecon Agung Tbk (SMRA).

Tabel 1. Penilaian saham tujuh belas emiten subsektor properti dan real estate terpilih dengan pendekatan Price Earning Ratio (PER) tahun 2009-2012 


\begin{tabular}{|c|c|c|c|c|c|c|c|c|}
\hline & \multicolumn{2}{|c|}{ Tahun 2009} & \multicolumn{2}{|c|}{ Tahun 2010} & \multicolumn{2}{|c|}{ Tahun 2011} & \multicolumn{2}{|c|}{ Tahun 2012} \\
\hline $\begin{array}{c}\text { PER } \\
\text { Subsektor }\end{array}$ & \multicolumn{2}{|r|}{34,1} & \multicolumn{2}{|r|}{20,13} & \multicolumn{2}{|r|}{20,56} & \multicolumn{2}{|r|}{38,97} \\
\hline Emiten & PER & Keterangan & PER & Keterangan & PER & Keterangan & PER & Keterangan \\
\hline (1) & (2) & (3) & (4) & (5) & (6) & (7) & (8) & (9) \\
\hline ASRI & 31,2 & underpriced & 18,1 & underpriced & 20,2 & underpriced & 17,3 & underpriced \\
\hline BAPA & 5,7 & underpriced & 12,8 & underpriced & 17,6 & underpriced & 18,9 & underpriced \\
\hline CTRA & 47,8 & overpriced & 24,4 & overpriced & 22,1 & overpriced & 19,3 & underpriced \\
\hline CTRP & 31,1 & underpriced & 16,8 & underpriced & 26,6 & overpriced & 18,5 & underpriced \\
\hline CTRS & 24,9 & underpriced & 17,2 & underpriced & 14,9 & underpriced & 20,2 & underpriced \\
\hline COWL & 11,8 & underpriced & 10,9 & underpriced & 5,1 & underpriced & 14,0 & underpriced \\
\hline SCBD & 6,3 & underpriced & 21,7 & overpriced & 34,2 & overpriced & 41,6 & overpriced \\
\hline DART & 17,7 & underpriced & 19,9 & underpriced & 22,5 & overpriced & 14,8 & underpriced \\
\hline DUTI & 6,2 & underpriced & 13,5 & underpriced & 8,8 & underpriced & 10,9 & underpriced \\
\hline GMTD & 1,1 & underpriced & 2,4 & underpriced & 1,4 & underpriced & 1,0 & underpriced \\
\hline JRPT & 10,9 & underpriced & 15,6 & underpriced & 16,7 & underpriced & 31,0 & underpriced \\
\hline LAMI & 14,9 & underpriced & 12,1 & underpriced & 5,4 & underpriced & 8,6 & underpriced \\
\hline LPCK & 7,0 & underpriced & 5,4 & underpriced & 7,0 & underpriced & 11,5 & underpriced \\
\hline LPKR & 26,8 & underpriced & 25,1 & overpriced & 31,8 & overpriced & 12,7 & underpriced \\
\hline MDLN & 173,6 & overpriced & 19,8 & underpriced & 8,0 & underpriced & 24,3 & underpriced \\
\hline GPRA & 12,3 & underpriced & 12,2 & underpriced & 11,7 & underpriced & 10,0 & underpriced \\
\hline SMRA & 32,0 & underpriced & 31,4 & overpriced & 27,7 & overpriced & 22,5 & underpriced \\
\hline
\end{tabular}

Sumber : Bursa Efek Indonesia, diolah

Secara umum, pergerakan harga saham emiten properti dan real esate terpilih searah dengan pergerakan indeks harga saham properti (gambar 3). Dari awal tahun 2009 hingga akhir tahun 2012, pergerakan harga saham keempat emiten cenderung mengalami kenaikan. Akan tetapi, selama tahun 2013, harga saham dari keempat emiten tersebut mengalami fluktuasi yang cukup tinggi, setelah mengalami kenaikan yang tajam pada awal tahun 2013, harga saham keempat emiten tersebut merosot pada kuartal III tahun 2013. Keempat emiten tersebut bahkan mengalami penurunan saham lebih dari 20 persen pada kuartal III tahun 2013. Penurunan tajam harga saham emiten properti dan real estate tersebut juga turut menekan indeks harga saham properti. Indeks harga saham sektor properti yang mengalami kenaikan signifikan padakuartal I tahun 2013 dan mencapai puncaknya pada level 483,27 pada kuartal II tahun 2013, merosot hingga pada level 384,04 pada kuartal III tahun 2013. 


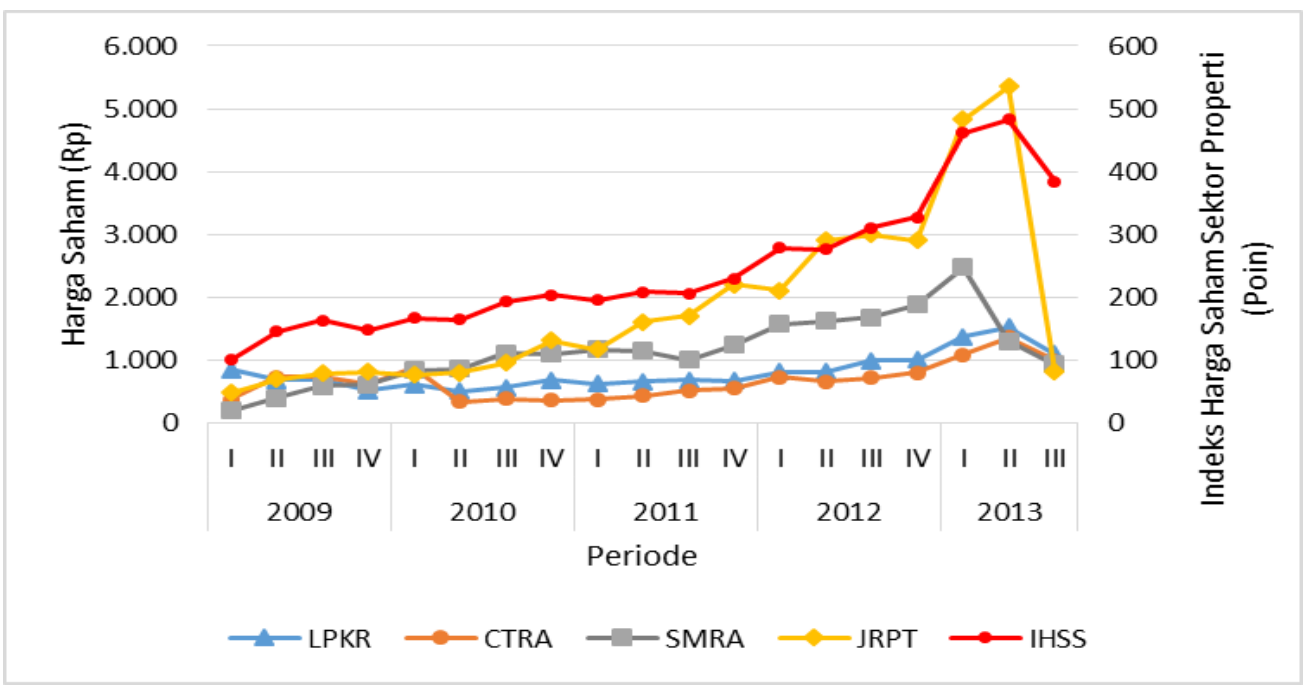

Sumber : Bursa Efek Indonesia, diolah

Gambar 3. Pergerakan harga saham empat emiten properti dan real estate terpilihtahun 2009 kuartal I - tahun 2013 kuartal III

Selama periode penelitian, pertumbuhan ekonomi menunjukkan pergerakan yang fluktuatif. Untuk setiap tahunnya, pertumbuhan ekonomi pada kuartal IV selalu negatif akibat siklus musiman pada sektor pertanian. Sementara itu, pergerakan nilai tukar rupiah terhadap dolar dan BI Rate menunjukkan tren menurun pada awal

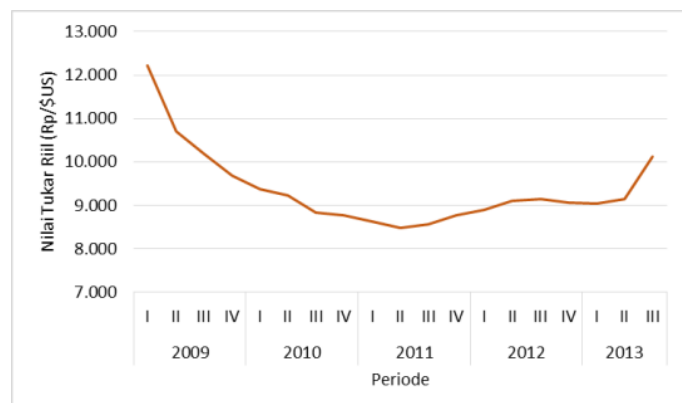

Sumber: Bank Indonesia dan

Organization for Economic

Cooperation Development

(OECD), diolah

Gambar 4. Perkembangan Nilai Tukar Riil

Rupiah terhadap Dolar tahun 2009

kuartal I - tahun 2013 kuartal III

Perkembangan kinerja emiten subsektor properti dan real estatemenunjukkan bahwa secara rata- periode penelitian, namun cenderung meningkat pada akhir periode penelitian seiring dengan kondisi perekonomian global dan domestik yang bergejolak (gambar 4 dan 5). Memburuknya kondisi perekonomian domestik tersebut terutama akibat pelebaran defisit transaksi berjalan yang terjadi sejak tahun 2012.

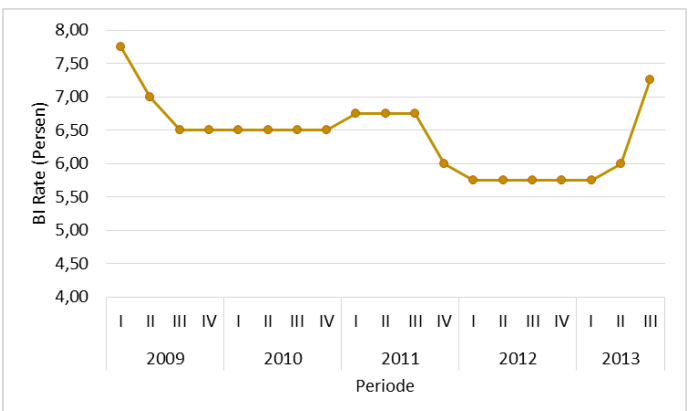

Sumber: Bank Indonesia, diolah

Gambar 5. Perkembangan Suku Bunga Bank Indonesia (BI Rate) tahun 2009 kuartal I -- tahun 2013 kuartal III

rata, hanya terdapat dua emiten dengan rata-rata ROA di atas 5 persen(gambar 6) yaitu Alam Sutera Realty Tbk (ASRI) 
dan Lippo Cikarang Tbk (LPCK). Sementara itu, sebagian dari emiten subsektor properti dan real estate yang menjadi objek penelitian lebih mengandalkan dana pinjaman dibandingkan dengan modal sendiri, yang terlihat dari besarnya rata-rata
DAR yang melebihi 50 persen (gambar 7). Dilihat pergerakannya, secara umum pergerakan rata-rata $\mathrm{ROA}$ dan $\mathrm{BV}$ menunjukkan tren yang meningkat, sedangkan pergerakkan rata-rata DAR cukup stabil.

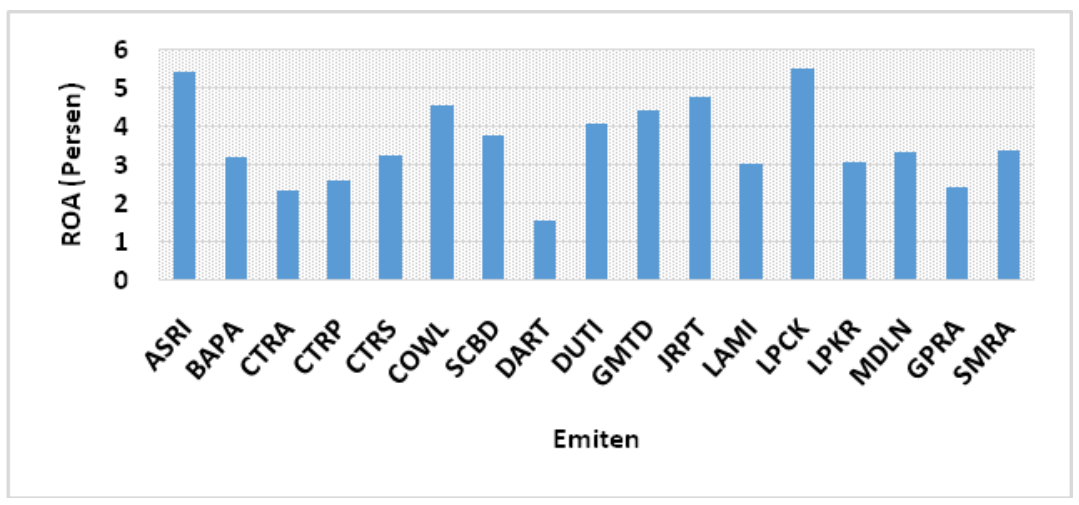

Sumber: Bursa Efek Indonesia, diolah

Gambar 6. Rata-rata Return on Asset (ROA) tujuh belas emiten properti dan real estate terpilih selamatahun 2009 kuartal I - tahun 2013 kuartal III

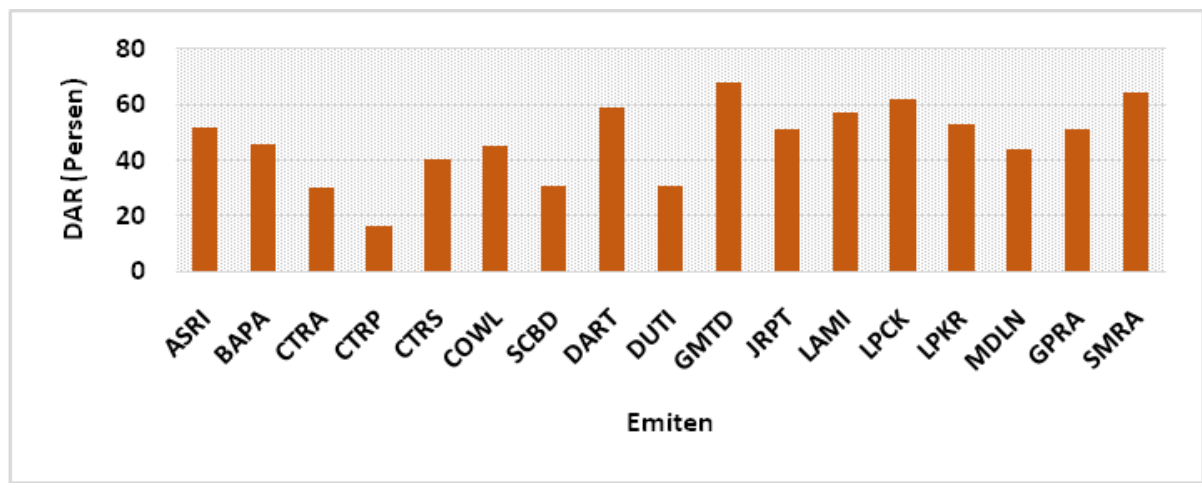

Sumber: Bursa Efek Indonesia, diolah

Gambar 7. Rata-rata Debt to Asset Ratio (DAR) tujuh belas emiten properti dan real estate terpilih selamatahun 2009 kuartal I - tahun 2013 kuartal III

Dalam pemilihan model terbaik, diperoleh model fixed effect dengan struktur matriks varian kovarian residual heteroskedastik dengan cross-sectional correlation sebagai model terbaik. Estimasi model yang dihasilkan adalah sebagai berikut :

$$
\begin{aligned}
& L N_{-}\left[\overrightarrow{A R G} A_{i t}=\left(0,7427+\alpha_{i}\right)+0,0523 P E_{t}^{8}-0,1992 L N \_N T R_{t}^{8}-0,2039 B I R_{t}^{8}\right. \\
& (1,6363) \quad(26,7519) \quad(-3,5286) \\
& +0,0466 R O A_{i t}^{8}+0,0151 D A R_{i t}+1,2519 L N_{-} B V_{i t}^{8} \\
& (43,6867) \quad(89,2983) \quad(94,7740)
\end{aligned}
$$


Catatan: $1 . *$ signifikan pada taraf uji 5 persen

2. Angka dalam tanda kurung ( ) menunjukkan nilai $t$-statistic

di mana $P E=$ pertumbuhan ekonomi, $N T R=$ nilai tukar riil rupiah terhadap dolar, $B I R=\mathrm{BI}$ rate, ROA=Return on Asset, DAR=Debt to Asset Ratio, dan BV=Book Value per Share

Dari hasil estimasi model terbaik dipeorolehProb (F-stat) sebesar 0,0000yang menunjukkan bahwa terdapat minimal satu variabel bebas dalam model yang memiliki pengaruh signifikan terhadap harga saham emiten subsektor properti dan real estate dengan tarafuji 5 persen. SedangkanAdjusted $R^{2}$ diperoleh sebesar 0,9958 yang menunjukkan bahwa keenam variabel bebas yang digunakan dalam model yaitu pertumbuhan ekonomi, nilai tukar rupiah terhadap dolar, BI Rate, ROA, DAR, dan BV mampu menjelaskan keragaman harga saham emiten subsektor properti dan real estate sebesar 99,58 persen.

Pengujian signifikansi variabel secara parsial dengan uji $t$ memberikan kesimpulan bahwa terdapat lima variabel yang memiliki pengaruh signifikan dan memiliki arah hubungan sesuai dengan hipotesis penelitian terhadap harga saham emiten properti dan real estate. Kelima variabel tersebut yaitu pertumbuhan ekonomi, nilai tukar riil rupiah terhadap dolar, BI Rate, ROA, dan BV. Sementara itu, DAR tidak memberikan pengaruh terhadap harga saham emiten properti dan real estate sesuai dengan hipotesis penelitian.

Pertumbuhan ekonomi yang diukur dengan pertumbuhan Produk Domestik Bruto memberikan pengaruh yang positif terhadap harga saham emiten properti dan real estate yang terdaftar di BEI. Pertumbuhan ekonomi yang baik secara umum menunjukkan tingkat perbaikan kesejahteraan masyarakat, dan hal ini biasanya diikuti dengan kegiatan pasar modal yang semakin bergairah (Anoraga dan Pakarti, 2006). Sedangkan nilai tukar rupiah terhadap dolar (kurs dolar) dan BI rate memberikan pengaruh negatif terhadap harga saham emiten properti dan real estate. Arah hubungan yang dihasilkan dalam penelitian ini sesuai dengan teori yang menyatakan nilai tukar rupiahmemiliki pengaruh utama terhadap perusahaan yang mengandalkan bahan baku impor (Sunariyah, 2011). Nurhidayat (2011) mengatakan sektor properti adalahindustri yang inputnya banyak dipengaruhioleh impor, sedangkan outputnya tidak dapat diekspor. Selain itu, Sunariyah (2011) menyatakan bahwa tingkat bunga yang tinggi merupakan signal negatif bagi pasar saham.

Kinerja emiten yang dilihat dari ROA, DAR, dan BV memberikan pengaruh yang positif terhadap harga saham emiten subsektor properti dan real estate. Arah hubungan dari ROA dan BV sesuai dengan hipotesis penelitian. Menurut Helfert (1996), daya tarik utama bagi pemegang saham atau investor adalah profitabilitasperusahaan. Sementara itu, pengaruh BV terhadap harga saham mengindikasikan bahwa investor bersedia memberikan penilaian saham yang lebih tinggi apabila ada jaminan keamanan (safety capital) atau nilai klaim atas aset bersih perusahaan yang semakin tinggi. Pengaruh DAR yang positif yang berlawanan teori dapat disebabkan karena dua hal seperti yang dijelaskan oleh Acheampong (2014). Pertama, sebagian besar utang bersifat jangka pendek sehingga pemenuhan kewajiban relatif cepat. Kedua, ketersediaan utang memungkinkan perusahaan melakukan ekspansi usaha dan investasi yang menguntungkan. 


\section{KESIMPULAN}

1. Berdasarkan pendekatan Price Earning Ratio (PER), secara umum harga saham emiten subsektor properti dan real estate yang menjadi objek pada penelitian ini masih relatifmurah sehingga relatif aman untuk dijadikan instrumen investasi.

2. Selama periode penelitian, pertumbuhan ekonomi menunjukkan pergerakan yang fluktuatif. Pergerakan nilai tukar rupiah terhadap dan BI Rate menunjukkan tren menurun pada awal periode penelitian, namun meningkat pada akhir periode penelitian. Sementara itu, melihat gambaran umum kinerja keuangan, sebagian emiten masih memiliki rata-rata ROA di bawah rata-rata total dan lebih mengandalkan dana pinjaman dibandingkan dengan modal sendiri. Jika dilihat pergerakannya, secara umum pergerakan rata-rata ROA dan $\mathrm{BV}$ menunjukkan tren yang meningkat, sedangkan pergerakkan rata-rata DAR cukup stabil.

3. Pertumbuhan ekonomi, ROA, dan BV memberikan pengaruh yang positif terhadap harga saham emiten subsektor properti dan real estate. Pergerakan nilai tukar rupiah terhadap dolar dan BI Rate memberikan pengaruh negatif terhadap harga saham emiten properti dan real estate.

\section{DAFTAR PUSTAKA}

[1] Acheampong, Prince, dkk. (2014). The Effect of Financial Leverage and Market Size on Stock Returns on the Ghana Stock Exchange: Evidence from Selected Stocks in the Manufacturing

Sector.International Journal of Financial Research, 5(1), 125134. Diakses pada tanggal 26 $\begin{array}{lc}\text { Mei } & 2014 \\ \text { www.sciedu.ca/ijfr }\end{array}$

melalui

[2] Anoraga, Pandji, dan Piji Pakarti. (2006). Pengantar Pasar Modal. Jakarta: Rineka Cipta.

[3] Arifin, Ali. (2007). Membaca Saham: Panduan Dasar Seni Berinvestasi. Yogyakarta: Andi.

[4] Badan Pengawas Pasar Modal. (2004). Studi tentang Investasi Syariah di Pasar Modal Indonesia. Jakarta: Bapepam.

[5] Hanafi, Mamduh M., dan Abdul Halim. (2000). Analisis Laporan Keuangan. Yogyakarta: UPP AMP YKPN.

[6] Helfert, Erich A. (1996). Teknik Analisis Keuangan (Edisi Kedelapan). Jakarta: Erlangga.

[7] Hijriah, Almas. (2007). Pengaruh Faktor Fundamental dan Risiko Sistematik terhadap Harga Saham Properti di Bursa Efek Jakarta[Tesis]. Medan: Universitas Sumatera Utara.

[8] Husnan, Suad. (1993). DasarDasar Teori Portofolio dan Analisis Sekuritas (Edisi Pertama). Yogyakarta: UPPAMP YKPN.

[9] Kartika, Andi. (2010). Volatilitas Harga Saham di Indonesia dan Malaysia. Jurnal Ilmu Ekonomi Aset. Volume 12 Nomor 1, halaman 17-26, Maret 2010. http://jurnal.widyamanggala.ac.id I 
[10]Nurhidayat, H. (2011). Deteksi Dini Periode Bearish Return Saham Sektor Properti Pendekatan Signal Nonparametrik. Finance and Banking Journal, 13(2), 110-127. Diakses pada tanggal 30 Mei
2014

melalui http://perbanasinstitute.ac.id.

[11] Sunariyah. (2011). Pengantar Pengetahuan Pasar Modal (Edisi Keenam). Yogyakarta: UPP STIM YKPN

Lampiran: Daftar nama dan kode emiten subsektor properti dan real estate yang terpilih sebagai objek penelitian

\begin{tabular}{|c|c|c|}
\hline No. & \multicolumn{1}{|c}{ Nama Emiten } & $\begin{array}{c}\text { Kode } \\
\text { Emiten }\end{array}$ \\
\hline 1. & Alam Sutera Realty Tbk & ASRI \\
\hline 2. & Bekasi Asri Pemula Tbk & BAPA \\
\hline 3. & Ciputra Development Tbk & CTRA \\
\hline 4. & Ciputra Property Tbk & CTRP \\
\hline 5. & Ciputra Surya Tbk & CTRS \\
\hline 6. & Cowell Development Tbk & COWL \\
\hline 7. & Danayasa Arthatama Tbk & SCBD \\
\hline 8. & Duta Anggada Realty Tbk & DART \\
\hline 9. & Duta Pertiwi Tbk & DUTI \\
\hline 10. & Gowa Makassar Tourism & Gevelopment Tbk \\
\hline 11. & Jaya Real Property Tbk & JRPT \\
\hline 12. & Lamicitra Nusantara Tbk & LAMI \\
\hline 13. & Lippo Cikarang Tbk & LPCK \\
\hline 14. & Lippo Karawaci & LPKR \\
\hline 15. & Modernland Realty Ltd Tbk & MDLN \\
\hline 16. & Perdana Gapuraprima Tbk & GPRA \\
\hline 17. & Summarecon Agung Tbk & SMRA \\
\hline
\end{tabular}

